ANIMAL MODELS IN PARASITOLOGY 
Related titles from the Macmillan Education:

Animal Models of Obesity: Michael F. W. Festing

Immunodeficient Animals for Cancer Research: Stephen Sparrow 


\title{
ANIMAL MODELS IN PARASITOLOGY
}

A Symposium held at the Royal Zoological Society, Regents Park, London, in March 1981

\author{
Edited by
}

DAWN G. OWEN

MRC Laboratory Animals Centre, Carshalton, Surrey, United Kingdom

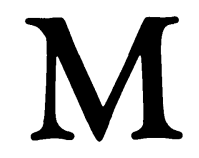


(C) The contributors 1982

Softcover reprint of the hardcover 1st edition 1982

All rights reserved. No part of this publication may be reproduced or transmitted, in any form or by any means, without permission.

First published 1982 by

Scientific and Medical Division

THE MACMILLAN PRESS LTD

London and Basingstoke

Companies and representatives throughout the world

ISBN 978-1-349-06138-9

ISBN 978-1-349-06136-5 (eBook)

DOI 10.1007978-1-349-06136-5 


\section{Symposium Contributors}

J. P. Ackers, London School of Hygiene and Tropical Medicine, Keppel Street, London WC1E 7HT

D. J. Bradley, London School of Hygiene and Tropical Medicine, Keppel Street, London WC1E 7HT

W. Bray, Imperial College Field Station, Ascot, Berks. SL5 7DE

F. E. Cox, Department of Zoology, King's College, Strand, London WC2R 2LS

J. D. Dargie, Animal Production and Health Section, Joint FAO/IAEA Division of Isotope and Radiation Applications of Atomic Energy for Food and Agriculture Development, Wagramstrasse 5, P.O. Box 100, A-1400 Vienna, Austria

D. A. Denham, London School of Hygiene and Tropical Medicine, Keppel Street, London WC1E 7HT

M. J. Doenhoff, London School of Hygiene and Tropical Medicine Field Station, Winches Farm, St Albans, Herts.

D. Dunne, London School of Hygiene and Tropical Medicine Field Station, Winches Farm, St Albans, Herts.

M. F. W. Festing, MRC Laboratory Animals Centre, Woodmansterne Road, Carshalton, Surrey SM5 4EF

P. C. C. Garnham, Imperial College Field Station, Ascot, Berks. SL5 7DE

R. Harrison, London School of Hygiene and Tropical Medicine Field Station, Winches Farm, St Albans, Herts.

O. Hassounah, London School of Hygiene and Tropical Medicine Field Station, Winches Farm, St Albans, Herts.

D. C. Jenkins, Wellcome Research Laboratories, Langley Court, Beckenham, Kent BR3 3BS

Michele Jungery, Nuffield Department of Clinical Medicine, John Radcliffe Hospital, Headington, Oxford OC3 9DU 
N. McHardy, Wellcome Research Laboratories, Langley Court, Beckenham, Kent BR3 3BS

Diane J. McLaren, National Institute for Medical Research, The Ridgeway, London NW7 1AA

H. Murare, London School of Hygiene and Tropical Medicine Field Station, Winches Farm, St Albans, Herts.

Bridget M. Ogilvie, The Wellcome Trust, 1 Park Square West, London NW1 4LJ

M. Elaine Rose, Houghton Poultry Research Station, Houghton, Cambs. PE17 2DA

A. Sabah, London School of Hygiene and Tropical Medicine Field Station, Winches Farm, St Albans, Herts.

S. R. Smithers, National Institute for Medical Research, The Ridgeway, London NW7 1AA

R. J. Terry, School of Biological Sciences, Brunel University, Uxbridge, Middlesex UB8 3PH

D. Wakelin, Department of Zoology, University of Nottingham, University Park, Nottingham NG7 2RD 


\section{Contents}

Symposium contributors $\quad \mathrm{v}$

Introduction $\quad$ ix

Acknowledgements $\quad$ xi

Session 1: The Importance of Genetic Susceptibility.

Chairman: J. G. M. Shire

1 Genetic manipulation of the host as a method in parasitology. M. F. W. Festing

2 The influence of genetic factors on the resistance of ruminants to gastrointestinal and trypanosome infections. J. D. Dargie

3 Mouse models of genetic variation in resistance to helminth parasites. D. Wakelin

4 Models of complex host-parasite relationships: murine leishmaniasis. D. J. Bradley

Session 2: Unusual Hosts. Chairman: F. E. G. Cox

5 Babesiosis in rodents and humans. F. E. G. Cox

6 Experience with a screen for macrofilaricidal activity using transplanted adult Brugia pahangi in the peritoneal cavities of Meriones unguiculatus. D. A. Denham

7 Primates in research on African trypanosomiasis and schistosomiasis. R. J. Terry

8 Primate hosts of malaria parasites, with particular reference to their use as models of the human disease. P. C. C. Garnham

Session 3: Immunodeprived Animals. Chairman: A. J. S. Davies

9 Nematodes in immunodeprived and genetically immunodefective rodents. Bridget M. Ogilvie and Michele Jungery

10 Immunodepressed animals as models for intestinal protozoan infections. M. Elaine Rose

$11 \mathrm{~T}$ cell deprivation and the persistence of experimental protozoan infections. J. P. Ackers

12 Schistosomiasis in the immunosuppressed host: studies on the host-parasite relationship of Schistosoma mansoni and S. bovis in T-cell-deprived and hydrocortisone-treated mice. M. Doenhoff, R. Harrison, A. Sabah, H. Murare, D. Dunne and O. Hassounah

Session 4: The Alternative. Chairman: G. A. M. Cross

13 In vitro screening tests for anthelmintics. D. C. Jenkins

14 Parasitic protozoa in macrophages in vitro. R. S. Bray 
15 The validity of in vitro models for the study of chemotherapeutic agents in theilerosis. N. McHardy

16 Immunity to schistosomiasis: in vitro versus in vivo models.

Diane J. McLaren and S. R. Smithers 


\section{Introduction}

The symposium reported here was convened in order to examine the model systems in use for the study of those helminth and protozoan parasites which cause diseases of great medical or veterinary importance.

The most frequently used laboratory animal hosts are the rat (Rattus norvegicus) and mouse (Mus musculus). Beginning at about the turn of the century, many inbred lines have been developed and spontaneous mutations maintained. This has led to the great diversity of rodent stocks currently available. The increasing use of gnotobiotic techniques since 1950 has subsequently allowed the mass production of microbiologically defined animals, and these two factors together have resulted in a highly sophisticated product being available for the research worker.

The first session of this symposium was concerned with the genetics of inbred strains, whilst the third dealt specifically with the relevant features of two particular mutant stocks - the nude mouse and the nude rat; interest in these centres largely around the many useful features related to their athymic condition.

In the second session some less common laboratory hosts (such as primates) and rodents other than rats and mice were discussed and in the final session the application of techniques in vitro to immunological and chemotherapeutic studies was considered.

The host, or culture flask, is of course only half of the system, and the choice of model parasite is also of prime importance. In many instances the species of parasite causing disease in man is not amenable to growth in a laboratory host (e.g. Wuchereria bancrofti or Onchocerca volvulus), or will only grow in a rare, threatened, or impossibly expensive host (such as the human malaria parasites in Aotus trivirgatus, the douroucouli monkey). Many parasites have been successfully persuaded to grow in artificial media, and some, such as the asexual forms of Plasmodium falciparum, will flourish in a simple culture (Trager and Jensen, 1978). If the organism is also difficult or impossible to culture then a completely artificial system is all that is available. Thus for the filariases, Litomosoides carinii in cotton rats (Sigmodon hispidus) became the favoured model, despite the taxonomic separation of both parasite and host from their principals in the disease. The establishment, then, of Brugia malayi in the peritoneal cavity of the Mongolian jird (Meriones unguiculatus) (Ash and Riley, 1970) is momentous for the future of chemotherapy and immunology of human filariasis.

Maintenance in vitro of parasites is very desirable for basic biochemistry; for mass production of antigens leading, one hopes, to practicable vaccines; and for many other biological purposes free from the complex immune responses of the animal host. However, the papers collected here make it clear 
that many animal model systems flourish and will remain, for the foreseeable future at least, the main basis for the collection of data on the parasitology of man and animals. It is hoped that this volume conveys to the reader some of the thought-provoking atmosphere of the symposium and the vigour of the debate.

\section{REFERENCES}

Ash, L. R. and Riley, J. M. (1970). J. Parasitology, 56, 969-73. Trager, W. and Jensen, J. S. (1978). Nature (Lond.), 273, 621. 


\section{Acknowledgements}

I would like to express my gratitude to Mr G.H. Townsend, Acting Director of the MRC Laboratory Animals Centre, Carshalton, for making this symposium possible. I would like to thank Professor J.G.M. Shire, Professor F.E. Cox, Professor A.J.S. Davies and Dr G.A.M. Cross for chairing the four sessions, and Dr D. Denham, Dr Bridget Ogilvie and Dr L. Joyner for their help and moral support in planning the programme. Special thanks are also extended to all the members of the Laboratory Animals Centre staff, who did so much hard work behind the scenes, particularly Miss Lynda Norris, who coped with all the typing. 